\title{
The Impact of Kalerwe Abattoir Wastewater Effluent on the Water Quality of the Nsooba Channel
}

\author{
Abdullahi Aden Shukri, Joseph Kyambadde and Joseph F Hawumba* \\ Department of Biochemistry and Sports Science, Makerere University, Uganda
}

Submission: February 23, 2017; Published: April 21, 2017

"Corresponding author: Joseph F Hawumba, Department of Biochemistry and Sports Science, School of Biological Sciences, College of Natural Sciences, P.O. Box 7082 Kampala, Uganda, Email: shukriaa1@gmail.com; jkyambadde@cns.mak.ac.ug; jhawumba@cns.mak.ac.ug

\begin{abstract}
The unregulated discharge of industrial wastewater from point sources into inland fresh water aquatic systems coupled with the resultant deterioration of water quality, are largely un-documented in many developing countries, Uganda inclusive. The aim of this study was to assess the impact of Kalerwe abattoir effluents on the water quality of Nsooba channel. In order to achieve this aim, water samples from five sampling points along Nsooba Channel: the first point upstream of the abattoir, the second at the abattoir point of discharge, the third one downstream immediately after mixing with Nsooba Channel water, the fourth point further downstream after other streams join the Nsooba channel, and the fifth at the point of entry into Lubiji wetland. Water samples were analyzed for. physico-chemical characteristics including: temperature, $\mathrm{pH}$, electrical conductivity (EC), total suspended solids (TSS), total dissolved solids, phosphate $\left(\mathrm{PO}_{4}{ }^{3}-\right)$, nitrate $\left(\mathrm{NO}_{3}{ }^{-}\right)$, nitrite $\left(\mathrm{NO}_{2}^{-}\right)$, ammonia nitrogen and chemical oxygen demand (COD), as well as for total bacterial counts, comprising: heterotrophic plate counts, total coli form counts and feacal coliform counts, respectively, Abattoir wastewater exhibited significantly higher levels of total dissolved solids $(1385.5+23.40 \mathrm{mg} / \mathrm{L})$, phosphate $\left.\left(\mathrm{PO}_{4}{ }^{3}\right)\right)(241.03+6.18 \mathrm{mg} / \mathrm{L})$, nitrate $\left(\mathrm{NO}_{3}{ }^{-}\right)(4.16 \pm 0.46 \mathrm{mg} / \mathrm{L})$, nitrite $\left(\mathrm{NO}_{2}{ }^{-}\right)(1.63 \pm 0.49 \mathrm{mg} / \mathrm{L} 0, \mathrm{ammonia}$ nitrogen $(63.58+1.51 \mathrm{mg} / \mathrm{L})$ and chemical oxygen demand (COD) $(12559 \pm 2019 \mathrm{mg} / \mathrm{L})$ compared to both upstream as well as downstream regions along Nsooba Channel. The mean heterotrophic bacterial counts and fecal coliform counts of abattoir effluent were $5.67 \times 10^{13}$ and $4.13 \times 10^{5} \mathrm{cfu} / 100 \mathrm{ml}$, respectively. However, there was a general decrease in both total heterotrophic bacterial counts $\left(4.2 \times 10^{13} \mathrm{cfu} / 100 \mathrm{~mL}\right)$ as well as fecal coliforms $\left(6.13 \times 10^{4} \mathrm{cfu} / 100 \mathrm{~mL}\right)$ at upstream and downstream of the abattoir discharge points along Nsooba channel. It was thus concluded that the release of Kalerwe abattoir effluents significantly impacts the water quality of Nsooba channel and eventually, Lubiji wetland. It is therefore imperative that Kalerwe abattoir undertakes the task of pre-treating its wastewater before releasing it into the channel.

Keywords: Abattoir; Wastewater; Effluent; Pre-treatment
\end{abstract}

\section{Introduction}

Slaughterhouses, also called abattoirs, are industries that are involved in the commercial slaughtering of animals such as cattle, goats, and sheep, among others, and processing of the meat for human consumption [1]. Abattoir operations generally use large quantities of water for washing the meat and in cleaning various process areas [2]. Consequently, abattoirs produce wastewater containing very high content of soluble and insoluble organics comprising, among others, blood, grease, inorganic and organic solids, paunch grass and salts as well as chemical added during processing operations [3-5]. Blood, undigested stomach contents (manure), fat, urine, and meat tissues are washed directly into the flowing water [6]. Indeed, blood constitutes the highest pollution load, followed by undigested feed (manure) and the two accounts for the high COD and BOD. Notably, high chemical oxygen demand (COD) values of, for instance, $375,000 \mathrm{mg} / \mathrm{L}$, are indicative of high organic pollutants of the receiving water sources, which in turn, leads to the depletions of oxygen in the course of their degradation within the ecosystem [7]. Moreover, the excess nutrients cause the water bodies to choke owing to the rapid growth of algal blooms thereby leading to eutrophication. In addition, abattoir effluents also contain large quantities of suspended solids, which range from 2333 to $8620 \mathrm{mg} / \mathrm{L}[5,8]$. Such levels of suspended solids greatly reduce the light available to photosynthetic organisms and eventually disrupt the balance of the ecosystem as the number of primary producers will be reduced. Besides, upon settling out the solids alter the characteristics of the river bed, making it an inappropriate habitat for many organisms [9].

A number of Abattoirs in developing countries lack facilities for treatment of abattoir effluents and consequently, the disposal 
of wastewater to both the terrestrial and aquatic environments could lead to transmission of pathogens to humans, the direct outcome of which would be the zoonotic diseases comprising, among others: Bacillosis, Salmonellosis, Brucellosis, and Helminthes [10]. Notably, pathogens associated with animal carcasses include rotaviruses, hepatitis E virus, Salmonella spp., E. coli, Yersinia enterocolitica, Campylobacter spp., Cryptosporidium parvum, and Giardia lamblia [11]. In Uganda high levels of contamination by both Escherichia coli and Enterococcus spp have been linked to abattoir wastewater, which drains into water bodies that are used as drinking water sources by the population [12]. The consequences of such infections range from temporary morbidity to mortality, especially in high-risk individuals such as the elderly and children. This calls for proper management of abattoir waste before its release into the environment [13]. Thus the study was undertaken with the aim of assessing the impact of Kalerwe abattoir effluent on Nsooba channel. The impact of Kalerwe Abattoir wastewater effluent on the water quality of the Nsooba Channel was assessed by determining both the microbial as well as the physico-chemical characteristics of the ensuing water mix.

\section{Materials and Methods}

\section{Preparation of reagents, solutions and culture medium}

Phenol solution: was prepared by mixing $11.1 \mathrm{~mL}$ of liquefied phenol (>89\%) with $95 \%(\mathrm{~V} / \mathrm{V}$ ) ethyl alcohol to a final volume of $100 \mathrm{~mL}$; Sodium nitroprusside: $(0.5 \%(\mathrm{w} / \mathrm{v}))$ was prepared by dissolving $0.5 \mathrm{~g}$ sodium nitroprusside in $100 \mathrm{~mL}$ of de-ionized water and stored in an amber bottle. Fresh solution was prepared every month; Sodium hypochlorite solution: $(5 \%(\mathrm{w} / \mathrm{v}))$ was prepared daily by dissolving $5 \mathrm{~g}$ sodium hypochlorite in distilled water to a final volume of $100 \mathrm{~mL}$. When a commercial solution was used, it was replaced every after two months; Oxidizing solution: was prepared by mixing $100 \mathrm{~mL}$ of alkaline citrate solution (comprising in $\mathrm{g} / \mathrm{L}$ of de-ionized water: trisodium citrate $(200 \mathrm{~g})$ and sodium hydroxide $(10 \mathrm{~g})$ and mixed with $25 \mathrm{~mL}$ sodium hypochlorite) with $100 \mathrm{~mL}$ of mercuric sulfate (prepared by dissolving $8 \mathrm{~g}$ red mercuric oxide (HgO) in $50 \mathrm{~mL}$ of 5 times dilute sulfuric acid $\left(10 \mathrm{~mL}\right.$ conc. $\mathrm{H}_{2} \mathrm{SO}_{4}: 40 \mathrm{~mL}$ de-ionized water] and final volume made up to $100 \mathrm{~mL}$ with ammonia-free de-ionized water); Digestion solution: (Sulfuric acid-mercuric sulfate-potassium sulfate solution) was prepared by dissolving $133 \mathrm{~g}$ of $\mathrm{K}_{2} \mathrm{SO}_{4}$ in $700 \mathrm{~mL}$ of ammonia-free deionized water and the resultant solutions acidified using 200 $\mathrm{mL}$ of conc. $\mathrm{H}_{2} \mathrm{SO}_{4}$. Thereafter, twenty five milliliters $(25 \mathrm{~mL})$ of mercuric sulfate solution was added and the final volume made up to $1 \mathrm{~L}$ using ammonia-free de-ionized water; Colour reagent for determination of total nitrogen: A solution of: N-1 naphthylethylenediamine-dihydrochloride (NEDD) was first prepared by dissolving $0.2 \mathrm{~g}$ of NEDD in deionized water. Thereafter, the colour reagent was constituted by mixing $90 \mathrm{~mL}$ of DI water, $50 \mathrm{~mL}$ of orthophosphoric acid and 57.5mL of NEDD. Finally, $5 \mathrm{~g}$ of sulphanilamide was dissolved in the resultant mixture and the final volume made up to $200 \mathrm{~mL}$ with DI; Reagents for total phosphorus; The reagents for determination of total phosphate comprised: a) phenolphthalein indicator aqueous solution (prepared by dissolving $0.1 \mathrm{~g}$ phenolphthalein in $10 \mathrm{~mL}$ ethanol), b) Sulphuric acid solution (prepared by adding drop-by-drop $300 \mathrm{~mL}$ of conc. $\mathrm{H}_{2} \mathrm{SO}_{4}$ to approximately $600 \mathrm{~mL}$ of distilled water and then diluting to $1 \mathrm{~L}$ with distilled water); c) Either ammonium persulfate, $\left(\mathrm{NH}_{4}\right)_{2} \mathrm{~S}_{2} \mathrm{O}_{8}$, or potassium persulfate $\mathrm{K}_{2} \mathrm{~S}_{2} \mathrm{O}_{8}$ solid $\left(0.5 \mathrm{~g}\right.$ ); and d) $5 \mathrm{~N}$ sulfuric acid $\left(\mathrm{H}_{2} \mathrm{SO}_{4}\right)$ : (prepared by adding drop-by-drop $70 \mathrm{~mL}$ conc. $\mathrm{H}_{2} \mathrm{SO}_{4} 400 \mathrm{~mL}$ of distilled water making it up to $500 \mathrm{~mL}$ with distilled water; Reagents for ortho-phosphate determination/Combined reagent: The reagents for determination of total phosphate comprised: a) Sulfuric Acid $\left(\mathrm{H}_{2} \mathrm{SO}_{4}\right) 5 \mathrm{~N}$ : (prepared by adding drop-by-drop $140 \mathrm{~mL}$ concentrated sulfuric acid to approximately $600 \mathrm{~mL}$ deionized (DI) water and then diluting to $1 \mathrm{~L}$ with DI; b) Potassium Antimonyl Tartrate Solution: (prepared by dissolving $1.3715 \mathrm{~g}$ of Potassium Antimonyl Tartrate $\left(\mathrm{K}(\mathrm{SbO}) \mathrm{C}_{4} \mathrm{H}_{4} \mathrm{O}_{6} \cdot \frac{1 / 2}{2} \mathrm{H}_{2} \mathrm{O}\right)$ in $400 \mathrm{~mL}$ DI water in a $500 \mathrm{~mL}$ volumetric flask and dilute to volume with DI; c) Ammonium Molybdate Solution: (prepared by dissolving $10 \mathrm{~g}$ of Ammonium Molybdate $\left(\left(\mathrm{NH}_{4}\right)_{6} \mathrm{Mo}_{7} \mathrm{O}_{24}: 4 \mathrm{H}_{2} \mathrm{O}\right)$ in $250 \mathrm{~mL}$ distilled water. The solution was stable for about 1 month at $4 \pm 2$ ${ }^{\circ} \mathrm{C}$ from the date of preparation; and d) Ascorbic Acid, 0.1M: (was prepared by dissolving $3.52 \mathrm{~g}$ of ascorbic acid in $200 \mathrm{~mL}$ DI water. The solution was stable for about 1 week at $4 \pm 2{ }^{\circ} \mathrm{C}$. To prepare one hundred milliliters $(100 \mathrm{~mL})$ of combined reagent, $50 \mathrm{~mL}$ $5 \mathrm{~N} \mathrm{H}_{2} \mathrm{SO}_{4}, 5 \mathrm{~mL}$ potassium antimony tartrate, $15 \mathrm{~mL}$ ammonium molybdate, and $30 \mathrm{~mL}$ ascorbic acid were mixed, and enough water added to make $100 \mathrm{~mL}$. This reagent was always prepared fresh when required; and Ammonium chloride-EDTA solution: $13 \mathrm{~g} \mathrm{NH}_{4} \mathrm{Cl}$ and $1.7 \mathrm{~g}$ ethylenediamine tetracetate were dissolved in $800 \mathrm{~mL}$ of distilled water and the $\mathrm{pH}$ then adjusted to $\mathrm{pH} 8.5$ with conc. $\mathrm{NH} 4 \mathrm{OH}$. The final volume was adjusted to $1 \mathrm{~L}$ with distilled water. Nutrient agar medium: Nutrient agar formulation (Scharlab, S. L., Barcelona, Spain) comprised in g/L: meat extract $(1.0 \mathrm{~g})$, yeast extract $(2.0 \mathrm{~g})$, peptone $(5.0 \mathrm{~g})$ sodium chloride $(5.0 \mathrm{~g})$, and bacteriological agar $(15 \mathrm{~g})$. To prepare the medium, $28 \mathrm{~g}$ of the dry formulation was suspended in $1 \mathrm{~L}$ of distilled water and sterilerized by autoclaving (Briad and Tatlock type, England) at $121{ }^{\circ} \mathrm{C}$ for $20 \mathrm{~min}$. Glucose at $1 \% \mathrm{w} / \mathrm{v}$ concentration was always used when required in the medium.

Chromocult agar medium: Chromocult agar medium was prepared following the manufacturer's instructions. Briefly, $26.5 \mathrm{~g}$ of the dry powder was weighed and suspended in $1 \mathrm{~L}$ of distilled water and heat in a boiling water bath, with the contents stirred regularly to assist in dissolution (approximately $35 \mathrm{~min}$ ). Thereafter the medium was cooled to $45-50{ }^{\circ} \mathrm{C}$ and then plates were poured. If they were not used immediately, they were stored in the fridge at $4{ }^{\circ} \mathrm{C}$ until when required. All of the chemicals and reagents well of the highest purity possible.

\section{Description of the study area and sample collection}

The Kalerwe abattoir, which belongs to Kasita Young Farmers' Co-operative Society, is located at the northern side of Kampala City. It lies between $021^{\prime} \mathrm{N}$ latitude and $32^{\circ} 35^{\prime} \mathrm{E}$ 
longitudes, and situated in Kawempe Division, Kampala district (Figure 1). Approximately 250 to 400 cattle, 150 to 250 goats and 30 to 60 sheep are slaughtered daily with the slaughtering of animals done the way of Halal method that is preferred by Muslims. The abattoir works seven days a week, with peak activities starting at midnight and ending at $1.00 \mathrm{pm}$. Wastewater samples were collected from five sampling points distributed along Nsooba channel (Figure 1), whereby sampling point 1 was located $100 \mathrm{~m}$ upstream of the abattoir drainage point into the channel i.e. sampling point 2 . The remaining sampling points located downstream of the abattoir discharge point were as follows: the first downstream sampling point (point 3) was located $100 \mathrm{~m}$ from the discharge point, the second one (point 4) after the entry into the Nsooba channel of Kiyanja and Katanga streams, and the last one (point 5) located at the entry point of Nsooba channel into Lubigi wetland (Figure 1). Samples were collected in plastic bottles between $08.00 \mathrm{am}$ and $09.00 \mathrm{am}$, the time of peak activities at the abattoir. During sampling, sample bottles were rinsed with sampled water three times and then filled to the brim. The samples were labeled and transported to the laboratory, stored in the refrigerator at $4{ }^{\circ} \mathrm{C}$ prior to analysis (Figure 2).

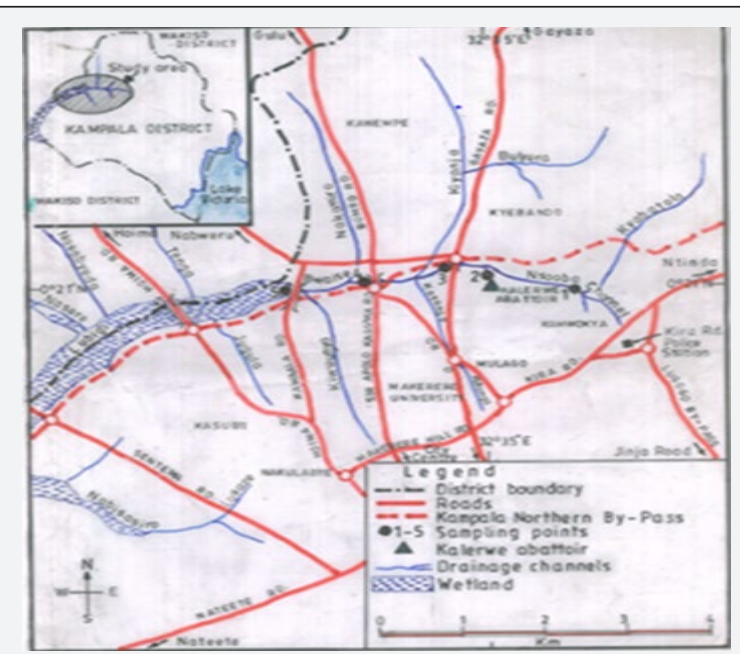

Figure 1:Location of the proposed study area in Kampala District.

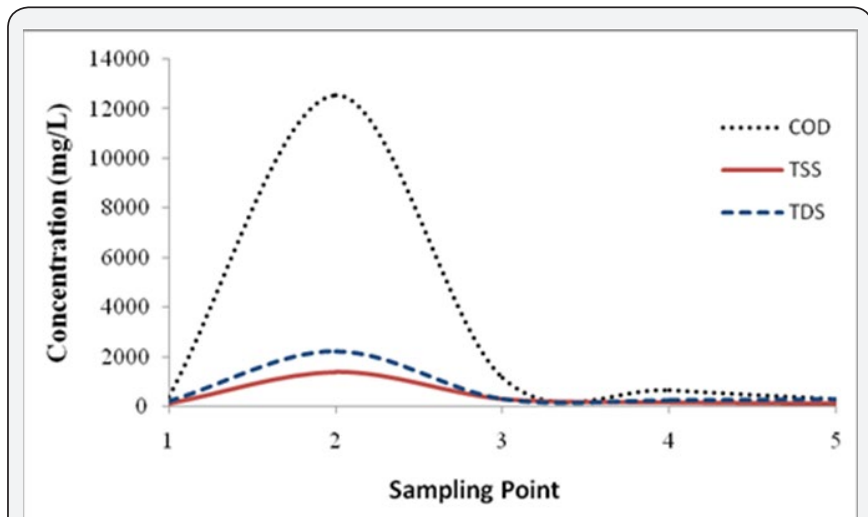

Figure 2: The trends of COD, TSS, and TDS levels in Nsooba channel.

\section{Determination of physico-chemical characteristics}

The physico-chemical characteristics were determined using standard analytical methods of water analysis [14]. Briefly, nonconservable parameters such as, temperature, $\mathrm{pH}$ and electrical conductivity were determined in situ. The $\mathrm{pH}$ was measured using a pH meter (Syberscan PC10, USA) while the temperature at the point of sample collection was determined using a thermometer. Chemical oxygen demand (COD) was determined using the closed reflux colorimetric method. Briefly, ampoules and caps were washed with $20 \% \mathrm{v} / \mathrm{v} \mathrm{H}_{2} \mathrm{SO}_{4}$ and rinsed with distilled water. To $2.5 \mathrm{~mL}$ of suitably diluted samples and distilled water (blank) was measured into ampoules, $1.5 \mathrm{~mL}$ of digestion solution (Section 2.1) was added followed by $3.5 \mathrm{~mL}$ of sulphuric acid reagent (Section 2.1) which was carefully run down inside of ampoules. The ampoules were tightly capped, inverted several times to mix thoroughly and then refluxed at $150{ }^{\circ} \mathrm{C}$ for 2 hours in preheated COD reactor (HACH, Colo, USA). After cooling to room temperature, the samples and blank were inverted several times and allowed to settle before measuring absorbance at $600 \mathrm{~nm}$. The COD was read directly using pre-calibrated spectrophotometer (Helios Aquamate, Thermo Electron Corporation, England) [15]. Total suspended solids (TSS), which is the amount of filterable solids, was determined by filtering, in triplicate, $20 \mathrm{~mL}$ of the samples through a microfiber glass filter and the amount of total suspended solids, in milligrams per litre $(\mathrm{mg} / \mathrm{l})$ of the sample, determined after drying in an oven (Model G90-C, Genlab, Widnes, England) at 103-105 ${ }^{\circ} \mathrm{C}$. The samples were subsequently cooled in a dessicator to constant weight, and sample volumes that yielded between 10 and $200 \mathrm{mg}$ of solid residue were chosen. Turbidity was determined spectrophotometrically at $543 \mathrm{~nm}$ using suitably diluted samples against the water blank.

\section{Determination of nitrogen levels}

Nitrogen in wastewater exists in majorly two forms: organic nitrogen and inorganic nitrogen (ammonia, nitrite and nitrate). In order to determine total nitrogen, the various forms were estimated: Ammonium nitrogen was determined by using a direct Nesslerization method. To $5 \mathrm{~mL}$ of suitably diluted sample in a clean test tube was added $0.2 \mathrm{~mL}$ Nessler reagent and mixed. The absorbance of the samples was measured using a spectrophotometer (Helios Aquamate NRTL/CEngland) at $425 \mathrm{~nm}$ after $15 \mathrm{~min}$ against sample blank [15]. In order to determine nitrite nitrogen, $0.2 \mathrm{~mL}$ of color reagent (Section 2.1) was added to $5 \mathrm{~mL}$ sample and mixed. After $10 \mathrm{~min}$, nitrite concentration was determined spectrophotometrically (Helios Aquamate, Thermo Electron Corporation, England) by measuring the absorbance at $543 \mathrm{~nm}$ against a reagent blank. At least one standard $\mathrm{NO}_{2}$ - was compared to a reduced $\mathrm{NO}_{3}$ - standard at the same concentration to verify reduction column efficiency. Nitrate was determined using the cadmium reduction method [14]. Briefly, to a $25.0 \mathrm{~mL}$ of the filtered sample, $75 \mathrm{~mL}$ of ammonium chloride-EDTA solution (Section 2.1) was added, mixed thoroughly and then poured onto the column containing copper-cadmium $(\mathrm{Cu}-\mathrm{Cd})$ granules. The 
reduced eluent was collected at a rate of $7-10 \mathrm{~mL}$ per minute. The first $25 \mathrm{~mL}$ was discarded and the rest of the eluent was collected in the original flask. Aliquots of $0.2 \mathrm{~mL}$ of color reagent (Section 2.1) were added to $5 \mathrm{~mL}$ of the reduced sample and mixed. After $10 \mathrm{~min}$ of color development, the nitrate concentration was determined spectrophotometrically (Helios Aquamate, Thermo Electron Corporation, England) by measuring the absorbance at $543 \mathrm{~nm}$ against a reagent blank. At least one standard $\mathrm{NO}_{2}$ - was compared to a reduced $\mathrm{NO}_{3}$ - standard at the same concentration to verify reduction column efficiency.

Organic nitrogen was determined indirectly by first estimating total Kjeldahl nitrogen (TKN) and then calculating it from the difference between total kjeldahl nitrogen and ammonia nitrogen. Total nitrogen was determined using the Kjeldahl apparatus. Briefly, glutamic acid digestion check standard of $2.9 \mathrm{mg}$ nitrogen/L were prepared by diluting $29.0 \mathrm{~mL}$ of intermediate glutamic acid solution to $100 \mathrm{~mL}$. Digestion check standard was treated in the same way as samples. To a digestion flask, $20 \mathrm{~mL}$ of suitably diluted sample and standard was added to $10 \mathrm{~mL}$ digestion reagent (Section 2.1). The digestion flask was capped tightly, mixed by inverting twice, and then heat for $30 \mathrm{~min}$ in an autoclave to convert all nitrogen forms in the sample to nitrate. The digested sample was then slowly cooled to room temperature, $2.0 \mathrm{~mL}$ borate buffer solution was added, mixed by inverting at least twice and if necessary $\mathrm{pH}$ adjusted to between 7 and 9 . To a $25.0 \mathrm{~mL}$ of the digested sample, $75 \mathrm{~mL}$ of ammonium chloride-EDTA solution (Section 2.1) was added, mixed thoroughly and then poured onto the column containing copper-cadmium (Cu-Cd) granules.

The reduced sample was collected at a rate of $7-10 \mathrm{~mL}$ per minute. The first $25 \mathrm{~mL}$ was discarded and the rest of the sample was collected in the original flask. Aliquots of $0.2 \mathrm{~mL}$ of color reagent (Section 2.1) were added to $5 \mathrm{~mL}$ of the reduced sample and mixed. After $10 \mathrm{~min}$ of color development the nitrate concentration, which is a representation of total nitrogen, was determined spectrophotometrically (Helios Aquamate, Thermo Electron Corporation, England) by measuring the absorbance at $543 \mathrm{~nm}$ against a reagent blank. At least one standard $\mathrm{NO}_{2}$ - was compared to a reduced $\mathrm{NO}_{3}$ - standard at the same concentration to verify reduction column efficiency. Organic nitrogen was calculated from the difference between total kjeldahl nitrogen and ammonia nitrogen.

\section{Determination of phosphorus levels}

In order to estimate the phosphorus level, orthophosphate and total phosphate were determined on the wastewater samples. Total phosphate $\left(\mathrm{PO}_{4}{ }^{3}\right.$-) was determined calorimetrically by the persulfate digestion method [14]. Briefly, a drop of phenolphthalein indicator was added to $50 \mathrm{~mL}$ of a suitably diluted portion of the sample and mixed thoroughly. If a red color developed, sulfuric acid solution was added drop wise to just discharge the color. Then $1 \mathrm{~mL} 1 \mathrm{~N} \mathrm{H}_{2} \mathrm{SO}^{4}$ solution and $0.5 \mathrm{~g}$ solid $\mathrm{K}_{2} \mathrm{~S}_{2} \mathrm{O}_{8}$ was added. This mixture was heat in an autoclave for $30 \mathrm{~min}$ to convert Organic phosphates to orthophosphate and then allowed to cool to room temperature. A drop of phenolphthalein indicator solution was added and neutralized to faint pink color with $\mathrm{NaOH}$, then made up to $100 \mathrm{~mL}$ with distilled water. The orthophosphate concentration was determined by the ascorbic acid method whereby, $2.5 \mathrm{~mL}$ aliquots from the $100 \mathrm{~mL}$ above were pipetted into clean dry test tubes to which $0.4 \mathrm{~mL}$ combined reagent (Section 2.1) was added and mixed thoroughly. After $10 \mathrm{~min}$ absorbance of each sample was measured spectrophotometrically at $880 \mathrm{~nm}$, using reagent blank as the reference solution [15]. The calibration curve was prepared as described for the samples above from a series of standards between $0.15-1.30 \mathrm{mg} / \mathrm{l}$ using distilled water. The orthophosphate concentration was determined by the ascorbic acid method whereby, $2.5 \mathrm{~mL}$ aliquots from the $100 \mathrm{~mL}$ above were pipetted into clean, dry test tubes to which $0.4 \mathrm{~mL}$ combined reagent was added and mixed thoroughly. After at least $10 \mathrm{~min}$ but not more than $30 \mathrm{~min}$, absorbance of each sample was measured spectrophotometrically at $880 \mathrm{~nm}$, using reagent blank as the reference solution.

\section{Determination of fecal coliforms and total microbial plate counts}

In order to evaluate contamination of Nsooba channel by fecal material, feacal coliform (using E. coli as the indicator organism) was determined simultaneously using the Membrane filtration technique [16] on a Chromocult coliform agar (CCA) enriched with cefsulodin at $5 \mathrm{mg} / \mathrm{ml}$. Wastewater samples were serially diluted 10 -fold in peptone water and the volumes of the various dilutions of samples chosen so that the number of colonies to be counted on the membrane filters fell between 20 and 80 . Portions, in triplicate, of $100 \mathrm{ml}$ of the respective sample dilutions were filtered through cellulose nitrate membrane filters $(0.45 \mathrm{~mm}$ pore size) and the membranes incubated on Chromocult Coliform Agar plates at $35^{\circ} \mathrm{C}$ for 24 h. E. coli colonies were identified by the action on X-glucuronide whose cleavage by the enzyme: $\beta$-D-glucuronidase released dark blue colored products. Consequently, presumptive E. coli was identified as dark blue colonies. Total microbial count was determined by plating aliquots of $100 \mu \mathrm{l}$ of serially diluted wastewater samples on nutrient agar medium and incubating the plates at $35{ }^{\circ} \mathrm{C}$ for $24 \mathrm{~h}$. The highest dilution that would show from 50 to $100 \mathrm{cfu}$ on the agar plates were selected and used in calculating total bacterial counts. The values are means of three replicates.

\section{Results and Discussion}

\section{Impact of abattoir wastewater on the water quality of Nsooba Channel}

In order to evaluate the impact of abattoir wastewater effluent on the overall water quality of Nsooba channel, physico-chemical properties, nutrients loads as well as the bacteriological characteristics, upstream and downstream of the Kalerwe abattoir discharge point were determined as described in methods (Section 2.3 to 2.6). The physico-chemical 
properties of the Nsooba channel water before and after mixing with Kalerwe abattoir wastewater effluent at various sampling points are presented in Table 1 . The mean values obtained for pH were 8.210 \pm 0.187 upstream, 9.050 \pm 0.132 Kalerwe abattoir, $8.848 \pm 0.145$ and $8.665 \pm 0.180$ downstream and $8.225 \pm 0.177$ at the entry into Lubiji wetland. It was noted that the $\mathrm{pH}$ of the channel remained alkaline all through to Lubiji wetland. The $\mathrm{pH}$ increased from 8.2 to 8.8 when the effluent $(\mathrm{pH} 9.0)$ joined the channel and gradually fell to $\mathrm{pH} 8.2$ at entry into Lubiji wetland. The fall in $\mathrm{pH}$ values from $\mathrm{pH} 8.8$ to $\mathrm{pH} 8.2$ may be attributed to the dilution effects of the various streams that also drain into the channel before its entry into the wetland. Clearly, these $\mathrm{pH}$ values are outside the set standard of the National Environmental Management Authority (NEMA) of pH 6.8. Since $\mathrm{pH}$ is an indicator of water quality and the extent of pollution [17], thus the increase in alkaline values from 8.2 to 8.8 at the discharge point suggests that the effluent further negatively impacted the water quality of Nsooba channel. This, in turn, could affect aquatic life negatively because most of their metabolic activities are pH dependent [18]. Moreover, other physicochemical characters (Table 1) including: the chemical oxygen demand (COD), total suspended solids (TSS), total dissolved solids (TDS) and conductivity increased greatly as observed for sampling points 2 and 3 when compared to sampling point 1 , before the abattoir drained into the channel. For instance, the COD, TSS and TDS values of $1161 \pm 40 \mathrm{mg} / \mathrm{L}, 306.70 \pm 32.8 \mathrm{mg} / \mathrm{L}$, and $316.50 \pm 32.0 \mathrm{mg} / \mathrm{L}$, respectively, at sampling point 3 are higher than those at sampling point 1 i.e. $375.0 \pm 50.6 \mathrm{mg} / \mathrm{L}$, $113.96 \pm 2.75 \mathrm{mg} / \mathrm{L}$ and $228.50 \pm 6.59 \mathrm{mg} / \mathrm{L}$, respectively. Needless to say that at sampling point 3, Kiyonjo and Katema streams had already drained into the channel, thereby diluting its water. This clearly shows that the high values are contributed, in part, by the effluent from Kaler we abattoir. From this point (3) onwards, the values of all test parameters decreased with the nutrient ( $\mathrm{N}$ \& P) levels falling even below the NEMA set standards (Table $1 \&$ Figure $3 \& 4$ ). The very high total dissolved solids (TDS) and total suspended solids (TSS) are contributed by blood, undigested materials and cow dung that are released as waste after slaughtering the animals. Thus, very high quantity of oxygen is required to oxidize all of these organic materials into carbon dioxide and water, which in turn, contribute to the high level of COD at sampling points 2 and 3. This could probably explain the linear relationship between solids and COD [19]. Furthermore, both TSS and TDS provide possible substrates for both anaerobic and aerobic microorganism for their subsequent mineralization. Therefore, the net dilution by such streams as: Kiyonjo (from Kyebando area), Katema (from Mulago/Makerere area), Nakamiro (from Bwayise area) and Kiwuunya (from Nakulabye/Kassubi area), the sedimentation of some suspended solids, and the mineralization of the organic loads as the water moves away from the point of discharge, should partly explain the decrease in COD (20]. Downstream, it should, however, also be noted that the COD values obtained from this study were low compared to those of other investigators. For instance, reported a COD range of $947-2566 \mathrm{mg} / \mathrm{L}$ from Oshunkaye stream receiving Bodija abattoir wastewater, while from this study a range of 300 $1174 \mathrm{mg} / \mathrm{L}$ was recorded.

Table 1: Descriptive statistic of physico-chemical and bacteriological characteristics of Kalerwe abattoir effluent Parameters.

\begin{tabular}{|c|c|c|c|c|c|c|}
\hline \multirow{2}{*}{ Parameters } & \multicolumn{5}{|c|}{ Sampling Point } & \multirow{2}{*}{ NEMA Standards } \\
\hline & 1 & 2 & 3 & 4 & 5 & \\
\hline $\mathrm{PH}$ & $8.21 \pm 0.187$ & $9.05 \pm 0.132$ & $8.85 \pm 0.145$ & $8.665 \pm 0.180$ & $8.23 \pm 0.177$ & $6.0-8.0$ \\
\hline TSS (mg/L) & $113.96 \pm 2.75$ & $1385.50 \pm 23.40$ & $306.70 \pm 32.80$ & $159.85 \pm 5.07$ & $112.28 \pm 5.36$ & 100 \\
\hline TDS (mg/L) & $228.50 \pm 6.59$ & $2240 \pm 516$ & $316.50 \pm 32.0$ & $263.00 \pm 2.68$ & $294 \pm 3.08$ & 1200 \\
\hline Temperature $\left({ }^{\circ} \mathrm{C}\right)$ & $22.18 \pm 0.37$ & $22.65 \pm 0.34$ & $22.18 \pm 0.45$ & $21.98 \pm 0.40$ & $22.10 \pm 0.53$ & $20-35$ \\
\hline $\begin{array}{l}\text { Conductivity }(\mu \mathrm{S} / \\
\mathrm{cm})\end{array}$ & $460.50 \pm 9.37$ & $3588 \pm 385$ & $621.3 \pm 68.80$ & $465.30 \pm 63.4$ & $518.3 \pm 68.3$ & NA \\
\hline COD (mg/L) & $375.00 \pm 50.60$ & $12559 \pm 2019$ & $1161 \pm 400$ & $658 \pm 246$ & $300 \pm 23$ & 100 \\
\hline $\mathrm{TP}(\mathrm{mg} / \mathrm{L})$ & $8.77 \pm 1.01$ & $241.03 \pm 6.18$ & $17.94 \pm 0.78$ & $12.81 \pm 0.956$ & $11.98 \pm 0.94$ & 10 \\
\hline $\begin{array}{l}\text { Orthophosphate } \\
\text { (mg/L) }\end{array}$ & $2.22 \pm 0.88$ & $66.52 \pm 5.17$ & $6.26 \pm 1.75$ & $3.66 \pm 1.38$ & $3.16 \pm 1.68$ & 5 \\
\hline TKN (mg/L) & $15.66 \pm 1.82$ & $429 \pm 110$ & $28.97 \pm 7.47$ & $13.01 \pm 2.44$ & $13.71 \pm 4.25$ & 10 \\
\hline TON (mg/L) & $14.76 \pm 1.51$ & $365.42 \pm 98.50$ & $21.85 \pm 5.57$ & $10.91 \pm 1.53$ & $11.80 \pm 3.40$ & NA \\
\hline NO2 (mg/L) & $0.51 \pm 0.119$ & $1.63 \pm 0.49$ & $0.45 \pm 0.19$ & $0.32 \pm 0.108$ & $0.10 \pm 0.06$ & 2 \\
\hline $\mathrm{NO} 3(\mathrm{mg} / \mathrm{L})$ & $1.58 \pm 0.44$ & $4.16 \pm 0.46$ & $1.47 \pm 0.39$ & $0.61 \pm 0.07$ & $0.12 \pm 0.03$ & 20 \\
\hline NH4-N (mg/L) & $0.90 \pm 0.36$ & $63.58 \pm 1.51$ & $7.12 \pm 1.90$ & $2.10 \pm 0.91$ & $1.911 \pm 0.85$ & 10 \\
\hline $\begin{array}{c}\text { Total Bacterial } \\
\text { count } \\
\text { (cfu } / 100 \mathrm{~mL} \text { ) }\end{array}$ & $4.4 \times 1012$ & $5.7 \times 1013$ & $5.5 \times 1013$ & $4.4 \times 1013$ & $4.2 \times 1013$ & NA \\
\hline $\begin{array}{c}\text { Fecal coliforms } \\
\text { (cfu/100mL) }\end{array}$ & $1.4 \times 105$ & $4.13 \times 105$ & $3.34 \times 105$ & 1.4.x105 & $6.14 \times 104$ & NA \\
\hline
\end{tabular}




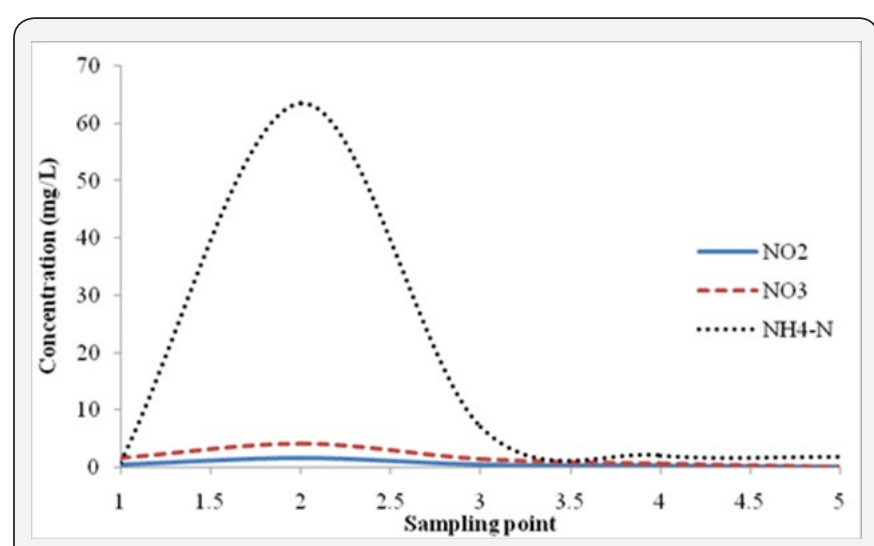

Figure 3: The trends of $\mathrm{NO} 3, \mathrm{NO} 2$, and NH4-N levels in Nsooba channel.

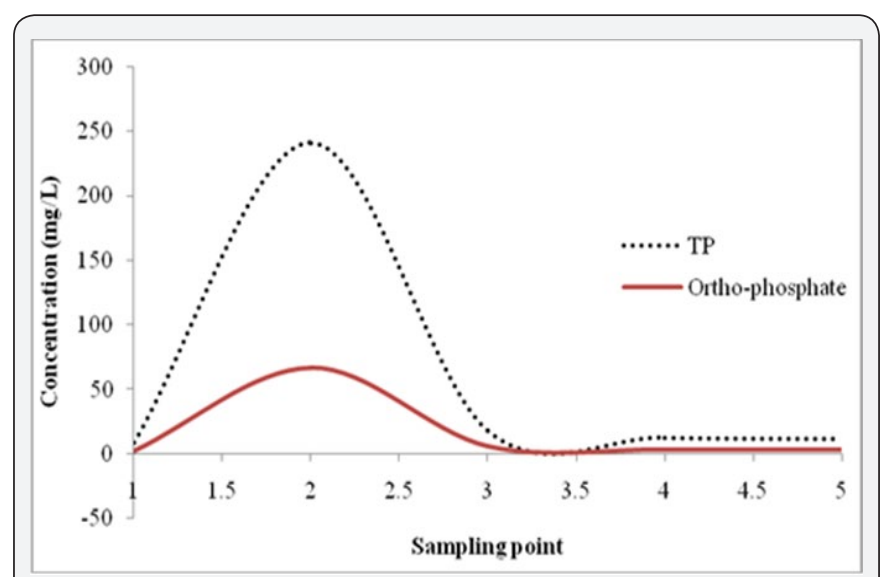

Figure 4: The trends of orthophosphate and total phosphate levels in Nsooba channel.

\section{Impact of nutrient overload on Nsooba Channel water quality}

Excessive nutrient (nitrogen and phosphorus) loading to the surface water bodies and groundwater is one of the leading causes of water quality impairment. As a matter of fact, nitrogen and phosphorous constitute the major nutrients responsible for eutrophication and other adverse impacts connected with nutrient overload [21,22]. While nitrogen is of paramount importance both in causing and controlling eutrophication in marine ecosystems, phosphorous is the limiting nutrient in freshwater (or non-saline) ecosystems [23]. As such, the contribution of these nutrients was assessed as described above. It was observed that the level of nitrogen, expressed as: total organic nitrogen, nitrate $\left(\mathrm{NO}_{3}\right)$, nitrite $\left(\mathrm{NO}_{2}\right)$ and ammonia nitrogen $\left(\mathrm{NH}_{4}-\mathrm{N}\right)$, respectively, was specifically high at the point of drainage (sampling point 2) of Kalerwe abattoir effluent into the channel (Table 1). Although the levels of nitrite and nitrate nitrogen were lower than those set by NEMA, organic nitrogen as well as ammonia nitrogen were high. On the other hand phosphorous levels too followed a similar trend whereby total phosphorous (TP) values (Table 1) were very high $(241.03 \pm 6.18 \mathrm{mg} / \mathrm{L})$ at the point of drainage into the Channel, only falling drastically $(17.94 \pm 0.78 \mathrm{mg} / \mathrm{L})$ at sampling point 3 . Phosphorous levels, however, remained higher than the NEMA set standards $(>10 \mathrm{mg} / \mathrm{L})$ until the Nsooba Channel drains into Lubigi wetland. Since ammonia nitrogen constituted a small fraction of the total kjeldahl nitrogen, it suggested that the bulk of nitrogen was in organic form. Therefore, it can be safely surmised that organic nitrogen and phosphorous are release slowly by the activities of microorganisms: bacteria and fungi, before its use by phytoplankton, zooplanktons and higher animals along the food chain [21]. That such microbial activity existed was observed by the drastic decrease in the concentrations of TP $(17.94 \pm 0.78 \mathrm{mg} / \mathrm{L}$ at sampling point 3 , from $241.03 \pm 6.18 \mathrm{mg} / \mathrm{L}$ at sampling point 2$)$ and TON $(21.85 \pm 5.57 \mathrm{mg} / \mathrm{L}$ at sampling point 3 , from $365.42 \pm 98.50 \mathrm{mg} / \mathrm{L}$ at sampling point 2 ), which was in tandem with the high bacterial counts $\left(5.5 \times 10^{13} \mathrm{cfu} / 100 \mathrm{~mL}\right)$ at sampling point 3,100 m downstream of the drainage point of Kalerwe abattoir. Along with such activity was the observed flourishing of water hyacinth downstream of the drainage point of Kaler we abattoir as well as algal blooms i.e. blue-green algae and red tides (harmful algal bloom (HAB]). A number of studies have catalogued health, ecological, and economical negative impacts of algal over-growths. The health impacts of harmful algal over growth have been associated with such toxins as: saxitoxins, brevetoxins, ciguatoxins, cyanotoxins, domoic acid, and okadaic acid have been associated with HABs in marine environments. Notably, HAB toxins may bio-accumulate among the lower members of the food chain and have been linked to illnesses and deaths in marine animals [21,22]. Ecologically, it has been established that algae growth may accelerate negative changes in algal species composition emanating from competition among species, which, in turn, leads to increased growth and sometimes dominance of toxic/harmful algal species [21]. Besides, excessive algal growth has not only been found to be linked to oxygen depletion, but has also been associated with reduction in water clarity, which as a consequence also results in reduced light availability for macrophytes. It follows that such changes in nutrients, light, and oxygen should favor some species over others and thereafter cause shifts in the structure of phytoplankton, zooplankton, and bottom-dwelling (benthic) communities [21-23]. Although this study did not explore the toxic effects of HABs, leave alone cataloguing the various species of algae that over grow in the channel, yet their presence indicated a possible link to such negative impacts.

\section{Impact on the Microbial water quality}

Waterborne human pathogens: viruses, bacteria, and protozoa, which may get washed into either drinking water supplies or receiving water bodies, come from animal and human fecal wastes [24] and are indicators of either poor sanitation or poor disposal of fecal waste as well as waste from a number of anthropogenic activities [22]. As a matter of fact, contaminated water supplies are the source for several waterborne diseases including: cholera, typhoid fever, shigellosis, salmonellosis, campylobacteriosis, giardiasis, cryptosporidiosis and Hepatitis 
A (WHO, 2004; quoted), among others. Since the density and diversity of these pathogenic microbes vary depending on the intensity and prevalence of the accruing infection, the detection, isolation, and identification of the responsible pathogens in wastewater are always difficult, expensive and time consuming. To circumvent this, indicator organisms are always used to determine the relative risk accruing from the possible presence of a particular pathogen in wastewater (24]. Thus, in order to assess the contribution of Kalerwe abattoir wastewater drainage on the microbial water quality of Nsooba channel, total bacterial counts, total coliforms, as well as the indicator organism: Escherichia coli; were determined as described in materials and methods (section 2.). The total bacterial and feacal coliform counts of Nsooba channel (represented as upstream sampling point 1), Kalerwe abattoir drainage into the channel (sampling point 2), and downstream to the receiving Lubiji swamp are shown in Table 1. It was noted that abattoir effluent released the highest bacterial load $(5.7 \times 1013 \mathrm{cfu} / \mathrm{ml}$ at sampling point 2$)$, which remained higher $(5.5 \times 1013 \mathrm{cfu} / \mathrm{mL}$ at sampling point 3$)$ even after further dilution from streams: Kiyonjo (from Kyebando area), and Katema (from Mulago/Makerere area) (Figure 1). While the lowest bacterial load $(4.2 \times 1013 \mathrm{cfu} / \mathrm{mL})$ was recorded the point of entry into Lubiji swamp (sampling point 5), all of these values are far higher as to call for pretreatment of the effluent before its release into Nsooba channel. On the other hand, fecal coliform counts ranging from $1.4 \times 105 \mathrm{cfu} / 100 \mathrm{~mL}$ (upstream of the discharge point i.e. sampling point 2) through the highs of $4.13 \times 105$ and 3.34x105 (at the point abattoir effluent discharge) and downstream $(100 \mathrm{~m}$ away from the point of discharge i.e. sampling point 3) clearly indicated feacal contamination of the water of Nsooba channel. Since feacal coliforms and specifically E. coli counts are often used as surrogates to measure for gastroenteric pathogens, the presence of $E$. coli provided sufficient evidence of the possible presence of pathogenic organisms from the untreated abattoir wastewater being discharged into the channel [24-26].

\section{Conclusion}

This study revealed that the structural system of animal slaughter used at Kalerwe abattoir is very poor, with blood, undigested feeds and other unwanted materials washed directly in to the drains and finally as effluent discharged in to Nsooba channel. The resultant high strength effluent further negatively impacts the quality of the water of Nsooba channel as observed by the increase in COD as well as microbial overload, indicative of too much nutrient overload. The presence of algal blooms and feacal coliforms, as indicated by the presence of E. coli, attests to possible health problems associated with both HABs and poor water sanitation. Since Nsooba channel drains into Lubigi wetland, which in turn, also drains into Lake Victoria, the major source of drinking water for a population in excess of 5 million, Kalerwe abattoir effluent ought to receive primary treatment before its release into Nsooba channel.

\section{Acknowledgment}

The authors acknowledge financial support from the Banadir University and Abdirahman Ahmed towards this study. This work also received support from the Department of Biochemistry and Sports Science, Makerere University which provided technical as well as infrastructural support.

\section{References}

1. Neboh H, Ilusanya O, Ezekoye C, Orji F (2013) Assessment of IjebuIgbo Abattoir effluent and its impact on the ecology of the receiving soil and river. Journal of Environmental Science, Toxicology and Food Technology 7(5): 61-67.

2. Sajidu S, Masamba W, Henry E, Kuyeli S (2007) Water quality assessment in streams and wastewater treatment plants of Blantyre, Malawi. Physics and Chemistry of the Earth 32(15): 1391-1398.

3. Cournoyer MS (1996) Sanitation and stabilization of slaughter-house sludges through compositing. In: Proceedings of the Canadian Meat Research Institute Technology Symposium. Ontario, Canadian Meat Research Institute, Toronto, Canada, pp. 1-7.

4. Massé D, Masse L (2000) Characterization of wastewater. Canadian Agricultural Engineering 42(3): 1-8.

5. Raheem N, Morenikeji O (2008) Impact of abattoir effluents on surface waters of the Alamuyo stream in Ibadan. Journal of Applied Sciences and Environmental Management 12(1): 73-77.

6. Liu YY, Haynes R (2011) Origin, nature, and treatment of effluents from dairy and meat processing factories and the effects of their irrigation on the quality of agricultural soils. Critical Reviews in Environmental Science and Technology 41(17): 1531-1599.

7. Trift W, Schuchardt F (1992) Materials flows and possibilities of treating liquid and solid wastes from slaughter houses in Germany. Bioresource Technology 41: 235-243.

8. Mittal GS (2004) Characterization of the effluent wastewater from abattoirs for land application. Food Reviews International 20(3): 229256.

9. Longe E, Omole D (2008) Analysis of pollution status of river Illo, Ota, Nigeria. The Environmentalist 28(4): 451-457.

10. Cadmus SIB, Olugasa BO, Ogundipe GAT ( 1999) The prevalence and zoonotic importance of bovine tuberculosis in Ibadan Paper presented at the The $37^{\text {th }}$ Annual Congress of the Nigerian Veterinary Medical Association, Nigeria.

11. Sobsey M, Khatib L, Hill V, Alocilja E, Pillai S (2002) Pathogens in Animal Wastes and the Impacts of Waste Management Practices on their Survival, Transport, and Fate. White paper for The National Center for Manure \& Agricultural Waste Management.

12. Svanström P (2014) Pathogens and antibiotic resistant bacteria in abattoir waste and animals.

13. Coker D (2001) Crime control and feminist law reform in domestic violence law: A critical review. Buffalo Criminal Law Review 4(2): 801860.

14. Apha A (1995) WEF, 1995. Standard methods for the examination of water and wastewater, 1.

15. Apha A (1998) WPCF, 1998. Standard methods for the examination of water and wastewater, 20.

16. Byamukama D, Kansiime F, Mach RL, Farnleitner AH (2000) Determination of Escherichia coli contamination with chromocult coliform agar showed a high level of discrimination efficiency for differing fecal pollution levels in tropical waters of Kampala, Uganda. 
Applied and Environmental Microbiology 66(2): 864-868.

17. Jonnalagadda S, Mhere G (2001) Water quality of the Odzi River in the eastern highlands of Zimbabwe. Water Research 35(10): 2371-2376.

18. Chen C, Idzerda Y, Lin HJ, Smith N, Meigs G, et al. (1995) Experimental confirmation of the X-ray magnetic circular dichroism sum rules for iron and cobalt. Physical review letters 75(1): 152-155.

19. Osibanjo 0, Adie G (2007) Impact of effluent from Bodija abattoir on the physicochemical parameters of Oshunkaye stream in Ibadan City, Nigeria. African Journal of Biotechnology 6(15).

20. Adeogun AI, Ofudje AE, Idowu M, Kareem SO (2011) Equilibrium, Kinetics and Thermodynamic Studies of the Biosorption of Mn (II) Ions from Aqueous Solution by Raw and Acid-Treated Corncob Biomass. Bio Resources 6(4): 4117-4134.

21. Environmental Protection Agency (EPA) Proposed Rules [40 CFR Part 131] (2012) Water Quality Standards for the State of Florida's Estuaries, Coastal Waters, and South Florida Inland Flowing Waters: Federal Register 77(243): 74924-74985.
22. Environmental Protection Agency (EPA) (2015) A compilation of Cost data Associated with Impact and Control of Nutrient pollution. U. S. Environmental Protection Agency. Office of Water EPA-820-F-15-096, pp. 1-120.

23. Howarth R, Anderson D, Cloern J, Elfring C, Hopkinson C, et al. (2000) Nutrient Pollution of Coastal Rivers, Bays, and Seas. Issues in Ecology 7: 1-17.

24. Akpor OB (2011) Wastewater Effluent Discharge: Effects and Treatment Processes. $3^{\text {rd }}$ International Conference on Chemical, Biological and Environmental Engineering IPCBEE. IACSIT Press, Singapore, pp. 8591.

25. Miner JR, Lipper RI, Fina LR, Funk JW (1966) Cattle feedlot runoff and its nature and variation Water. Pollution Control Federation 38(10): 1582-1591.

26. Addy VJ, Kabough TJ, Mohammed HK, Aliyu I (2015) Microbiological Assessment of Abattoir Effluent on Water Quality of River Katsina-ala, Nigeria. International Letters of Natural Sciences 39: 73-79.

\section{Your next submission with Juniper Publishers will reach you the below assets}

- Quality Editorial service

- Swift Peer Review

- Reprints availability

- E-prints Service

- Manuscript Podcast for convenient understanding

- Global attainment for your research

- Manuscript accessibility in different formats

( Pdf, E-pub, Full Text, Audio)

- Unceasing customer service

Track the below URL for one-step submission

https://juniperpublishers.com/online-submission.php 